\section{Heterogeneous primary melts of the Emeishan picrites: Contribution from eclogite to "plume" magmas}

\author{
M.B. KAMENETSKY ${ }^{1}$, V.S. KAMENETSKY ${ }^{1}$, CRAWFord ${ }^{1}$, \\ S.-L. Chung ${ }^{2}$, A.J.D.V. Kuzmin ${ }^{3}$, A.V. Sobolev ${ }^{3}$ \\ ${ }^{1}$ CODES, University of Tasmania, Australia (Maya.Kamenetsky \\ (a) utas.edu.au) \\ ${ }^{2}$ Department of Geosciences, National Taiwan University, \\ Taiwan (sunlin@ntu.edu.tw) \\ ${ }^{3}$ MPI, Mainz, Germany (asobolev@mpch-mainz.mpg.de)
}

The Late Permian Emeishan flood basalt province in SW China is characterised by unique occurrence of picritic lavas with high-Fo olivines. We aimed at reconstructing the compositions of parental/primary melts and their evolution during crystallisation, using olivine phenocrysts and olivine-hosted inclusions from picrite lavas in the Dukou area (Chung and Jahn, 1995). Picrites are massive high $\mathrm{MgO}$ rocks (16-18 $\mathrm{wt} \%$ ) with abundant olivine (Fo 75.9-91.6 mol \%) and clinopyroxene phenocrysts. Variable trace elements in olivine at a given Fo (e.g., $0.25-0.45 \mathrm{wt} \%$ $\mathrm{CaO}, 0.3-0.4 \mathrm{wt} \% \mathrm{NiO}$ ) suggest different parental melts, rather than control from crystal fractionation. $\mathrm{NiO}$ is exceptionally high (up to $0.5 \mathrm{wt} \%$ ) in some crystals Spinel inclusions in olivine are characterised by high $\mathrm{Cr} \#(50-82 \mathrm{~mol} \%)$ and variable $\mathrm{TiO}_{2}$ contents $(2-8 \mathrm{wt} \%)$ for a given composition of the host olivine.

Crystallised melt inclusions in olivine were heated at $1320^{\circ} \mathrm{C}$ in a vertical furnace and quenched into glass. The glass compositions were recalculated in order to account for $\mathrm{FeO}$ depletion (5-12 wt $\%$, c.f. $12 \mathrm{wt} \%$ in whole rocks) and to match the equilibrium with host olivines. Melt inclusions have broad geochemical similarities to the whole rocks and OIB, but the overall variations in major and trace elements and their ratios are significant (e.g., $\mathrm{CaO} / \mathrm{Al}_{2} \mathrm{O}_{3} 1-1.5 ; \mathrm{K}_{2} \mathrm{O} / \mathrm{TiO}_{2}$ 0.15-0.47; La/Sm 2.2-5.1; Gd/Yb 3.6-5.7). High $\mathrm{Gd} / \mathrm{Yb}$ point to large content of residual garnet in the melting source, possibly exceeding amount of garnet in a "plume" mantle source of OIB. Copper accumulates in the melt during crystal fractionation to very high levels ( $\sim 600 \mathrm{ppm})$.

Variations in the compositions of olivine, spinel and melt inclusions argue for significant compositional heterogeneities among parental magmas. We invoke mixing between two principal magmas that derived from the mantle peridotite ("plume") and pyroxenite. The latter was formed by reaction between partial melt derived from crustal eclogite and mantle peridotite (Sobolev et al., 2005). The presence of reaction pyroxenite in the source is justified by high $\mathrm{Ni}$ and low $\mathrm{Mn}$ in olivine phenocrysts (Sobolev et al., 2005), the elevated MREE/HREE in melt inclusions and unradiogenic $\mathrm{Nd}$ isotopes $(\varepsilon \mathrm{Nd}(\mathrm{T})=+4$ to -4 Chung and Jahn, 1995).

\section{References}

Chung, S.L., Jahn, B.-M., 1995. Geology 23, 889-892.

Sobolev, A.V. et al., 2005. Nature 434, 590-597.

\section{Exceptional mobility of $\mathrm{Cu}$ and $\mathrm{Ag}$ inferred from experiments with rhyolitic melt inclusions in quartz}

\author{
V.S. Kamenetsky, L.V. Danyushevsky
}

CODES, University of Tasmania, Australia (Dima. Kamenetsky@, utas.edu.au)

Quantification of abundances of metallic elements in magmas using melt inclusion approach helps to understand metal partitioning during crystallization and degassing, and the role of different melts in contributing to economic mineralization. The outstanding question is whether inherently metal-enriched (fertile) magmas exist in nature and originate metal-bearing fluids, or whether occurrence of mineralization is governed by other factors. The existing discrepancy in the results obtained from unheated and reheated inclusions of felsic melts in quartz warranted this study which tests the possibility of metals being introduced into high-Si melt inclusions during experimental heating.

Heating experiments with quartz-hosted melt inclusions (MI) from the Taupo rhyolites were performed in a muffle furnace at different conditions (Kamenetsky and Danyushevsky, 2005). Quenched MI were subsequently analysed for 30 elements by LA-ICPMS and compared with unheated inclusions and matrix glasses.

Diffusion into melt inclusions is noted for $\mathrm{Cu}$ and $\mathrm{Ag}$ only (increase by $2-3$ orders of magnitude), but diffusion out of melt inclusions is recorded for $\mathrm{Cu}$ only. Absolute concentrations of $\mathrm{Cu}$ and $\mathrm{Ag}$ and $\mathrm{Cu} / \mathrm{Ag}$ vary among heated melt inclusions within the same grain. No obvious correlation exists between $\mathrm{Cu}-\mathrm{Ag}$ abundances and 1) inclusions sizes, 2) inclusions position in quartz (e.g., core-rim). We infer that diffusion is determined by specific ("volatile") properties of the $\mathrm{Cu}$ and $\mathrm{Ag}$ ions rather than a control from structural characteristics of quartz. Thus, phenomenal volatility of $\mathrm{Cu}$ and $\mathrm{Ag}$ can be accounted for when interpreting the results of other melt inclusion studies that showed metal enrichment in heated (remelted) melt inclusions compared to unheated inclusions from the same samples.

Our heating stage experiments and in situ analyses show strong $\mathrm{Cu}$ partitioning into aqueous saline fluids. Deagassing can account for $\mathrm{Cu}$ loss from the Taupo rhyolite magma during eruption, and thus low $\mathrm{Cu}$ content in the matrix glass $(1.7 \mathrm{ppm})$. On the other hand, the melt trapped as inclusions appears to be undegassed (up to 7-8 wt $\% \mathrm{H}_{2} \mathrm{O}$ ), and thus the original $\mathrm{Cu}$ should be at least $25 \mathrm{ppm}$ (based on a model $\mathrm{Cu} / \mathrm{Zn}=0.55$ ), not $2.8 \mathrm{ppm}$ as measured in unheated melt inclusions. The phenomenon of $\mathrm{Cu}$ diffusion out of melt inclusions suggests the possibility of re-equilibration of quartz-hosted melt inclusion with continuously $\mathrm{Cu}$ degassing magma during its ascent and eruption.

\section{Reference}

Kamenetsky, V.S., Danyushevsky, L.V., 2005. Am. Mineral. 90, 1674 1678.

doi:10.1016/j.gca.2006.06.614 